\title{
ANALISIS PERBANDINGAN KETELITIAN POSISI HASIL PENGUKURAN GNSS DARI KOMBINASI SATELIT GPS, GLONASS, DAN BEIDOU
}

\author{
Khomsin ${ }^{1}$, Ira M. Anjasmara², Wahyu Ristanto ${ }^{3}$ \\ 1,2,3 Departemen Teknik Geomatika, FTSLK-ITS, Kampus ITS Sukolilo, Surabaya, 60111, Indonesia \\ e-mail: ${ }^{1}$ khomsin95@yahoo.com, ${ }^{2}$ ira@geodesy.its.ac.id, ${ }^{3}$ ristanto69.wr@gmail.com
}

\begin{abstract}
Abstrak
GNSS (Global Satellite Navigation System) merupakan suatu istilah yang digunakan untuk mencakup seluruh sistem satelit navigasi global yang sudah beroperasi ataupun sedang dalam perencanaan. Sistem navigasi satelit global ini beberapa diantaranya yaitu GPS, GLONASS, dan BeiDou. Kesalahan akibat sedikitnya satelit saat pengambilan data, secara teoritis dapat teratasi dengan kemajuan teknologi receiver yang mampu menangkap berbagai sinyal satelit. $\mathrm{Hi}$ Target V30 adalah salah satu receiver GNSS yang mampu menangkap sinyal satelit GPS, GLONASS dan BeiDou, dengan semakin banyaknya sinyal satelit yang dapat diterima diharapkan dapat meningkatkan akurasi dari penentuan posisi. Dari penelitian ini menunjukkan bahwa penggunaan satelit BeiDou tidak terlalu memberi pengaruh terhadap satelit GPS, akan tetapi penggunaan satelit BeiDou menambah ketelitian dari satelit GLONASS. Hal ini ditunjukkan dengan adanya penurunan nilai pada selisih koordinat dan RMS error yang dihasilkan dari 1.068 $\mathrm{m}$ menjadi $0.371 \mathrm{~m}$. Penggunaan kombinasi satelit GPS + GLONASS + BeiDou dan GPS + GLONASS rata - rata menghasilkan ketelitian yang paling kecil dengan nilai RMS error yang tetap berada diangka millimeter, sedangkan penggunaan satelit GLONASS saja menghasilkan ketelitian yang paling besar diantara stategi yang digunakan terlihat dari nilai RMS error yang mencapai $0.585 \mathrm{~m}$ pada baseline $\mathrm{C} 2$
\end{abstract}

Kata kunci: GNSS, Satelit, Penentuan Posisi, Akurasi

\begin{abstract}
GNSS (Global Navigation Satellite System) is a term used for the entire global navigation satellite system that already operate or are in the planning. some of them namely GPS, GLONASS, and BeiDou. Errors due to less of satellite signal when measurement data, theoretically this can be resolved with the receiver technological advances that was able to capture a variety of satellite signals. Hi - Target V3O is one of GNSS receivers are able to catch GPS, GLONASS and BeiDou satellite signal. With more of satellite signals that can be received, we are expected to improve the accuracy of positioning. From this research, the use of BeiDou satellite not too give effect on the GPS satellites, but this increase the accuracy of the GLONASS satellite. This is provided by a reduction in value on difference coordinates and RMS error resulting from 1,068 $\mathrm{m}$ into $0371 \mathrm{~m}$. The use of GPS + GLONASS satellite combination + GPS + GLONASS and BeiDou provided the best precision with value of the RMS error remain in the millimeter fraction, on the other hand the use of GLONASS satellites alone provided the worst precision among apparently strategy used with the value of RMS error reach $0585 \mathrm{~m}$ on baseline $\mathrm{C2}$
\end{abstract}

Keywords: GNSS, Satellite, Positioning, Precision 


\section{PENDAHULUAN}

GNSS (Global Satellite Navigation System) merupakan suatu istilah yang digunakan untuk mencakup seluruh 98nalis satelit navigasi global yang sudah beroperasi ataupun sedang dalam perencanaan (Lechner \& Baumann 2000). Sistem navigasi satelit global ini beberapa diantaranya yaitu GPS, GLONASS, Galileo, BeiDou, IRNSS, dan QZSS (Bakara 2011). Penggunaan GNSS menjadikan survei extra-terrestrial menjadi lebih mudah dan ketelitian yang didapat juga bagus.

Segmen GNSS dibangun oleh 3 segmen, yaitu segmen angkasa yang terdiri atas satelit GNSS, segmen 98nalisa terdiri atas jaringan stasiun 98nalisa, dan segmen pengguna yang terdiri dari peralatan yang menerima sinyal satelit (NovAtel Inc 2015). Pada dasarnya GPS dapat digunakan setiap saat tanpa bergantung waktu dan cuaca, GPS dapat digunakan baik pada siang maupun malam hari, dalam kondisi cuaca yang buruk sekalipun seperti hujan ataupun kabut (Abidin 2007). Karena karakteristiknya ini maka penggunaan GPS dapat meningkatkan efisiensi dan fleksibilitas dari pelaksanaan aktivitasaktivitas yang terkait dengan penentuan posisi. Konsep dasar pada penentuan posisi dengan GPS adalah reseksi (pengikatan ke belakang) dengan jarak, yaitu dengan pengukuran jarak secara simultan ke beberapa satelit GPS yang koordinatnya telah diketahui (Rachmad 2016). Kebutuhan akan ketelitian posisi titik yang tinggi sangat diperlukan dalam berbagai aplikasi. Terdapat berbagai kesalahan dalam pengukuran GPS seperti multipath dan cycle slip yang dapat mempengaruhi ketelitian (EIRabbany 2002). Ketelitian posisi yang didapat dari suatu survei GPS secara umum akan bergantung pada 4 (empat) 98nalis, yaitu: ketelitian data yang digunakan, geometri pengamatan, strategi pengamatan yang digunakan, dan strategi pengolahan data yang diterapkan. Ketelitian data yang digunakan pada dasarnya akan bergantung pada 3 (tiga) 98nalis, yaitu: jenis data (pseudorange atau fase), kualitas dari receiver yang digunakan, serta level dari kesalahan dan bias yang mempengaruhi data pengamatan. Geometri pengamatan mencakup geometri pengamat (jaring) dan geometri satelit yang bergantung pada jumlah satelit, lokasi, dan distribusi satelit yang diterima. Secara teoriti semakin banyak jumlah satelit yang diterima, maka geometri satelit akan semakin baik (Izman \& Rudianto 2011).

Perkembangan teknologi receiver yang terus berkembang dapat mengatasi kesalahan akan kurang kuatnya geometri satelit saat pengambilan data (Gumilar dkk 2016). HiTarget V30 adalah salah satu receiver GNSS yang mampu menangkap sinyal satelit GPS, GLONASS dan BeiDou, dengan semakin banyaknya sinyal satelit yang dapat diterima diharapkan dapat meningkatkan akurasi dari penentuan posisi. Berdasarkan pada spesifikasi yang dimiliki oleh receiver $\mathrm{Hi}$ Target, akurasi yang dapat dihasilkan pada survei secara 98nalis yaitu $2.5 \mathrm{~mm}$ ketelitian horizontal dan $5 \mathrm{~mm}$ ketelitian vertical ( $\mathrm{Hi}$ Target 2015).

Pada penelitian ini akan dilakukan 98nalisa mengenai penggunaan 3 kombinasi satelit GPS, GLONASS dan BeiDou dengan receiver $\mathrm{Hi}$ Target $\mathrm{V} 30$ terhadap akurasi penentuan posisi. GPS merupakan satelit yang dikembangkan oleh Amerika Serikat. GLONASS dikembangkan oleh Uni Soviet (Rusia) (GLONASS 2018), dan BeiDou merupakan satelit navigasi yang dikembangkan oleh Cina (IAC 2017). Dengan semakin banyak digunakannya satelit maka akan didapatkan lebih banyak data dan diharapkan dapat menambah ketelitian survei GNSS

\section{METODOLOGI PENELITIAN}

\section{Lokasi Penelitian}

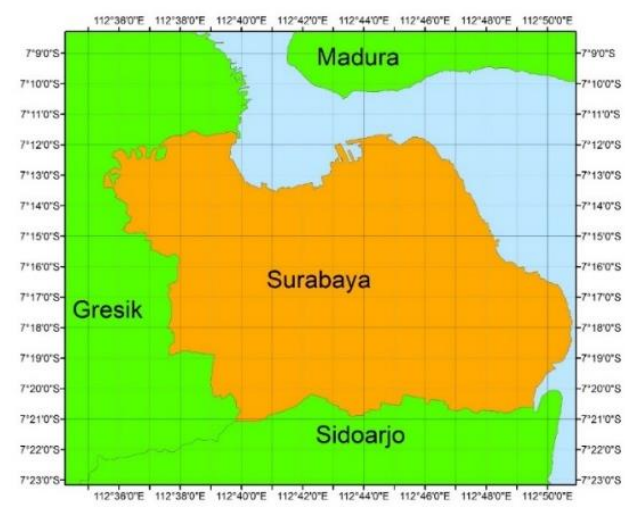

Gambar 1. Lokasi Pengukuran Kota Surabaya, Jawa Timur 
Pada penelitian ini dilakukan pengukuran GNSS sejumlah 8 titik yang berada di area Kota Surabaya, Jawa Timur yang berada pada koordinat $07^{\circ} 09^{\prime}-07^{\circ} 21^{\prime}$ LS dan $112^{\circ} 36^{\prime}-$ $112^{\circ} 54^{`} \mathrm{BT}$.

\section{Data}

Data primer yang digunakan pada penelitian ini adalah data survei GNSS dengan menggunakan receiver $\mathrm{Hi}$ Target $\mathrm{V} 30$ yang dapat menangkap sinyal satelit GPS, GLONASS, dan BeiDou. Receiver Hi Target V30 dapat dilihat pada Gambar 2 Data diperoleh dengan melakukan pengukuran langsung lapangan survei GNSS area Surabaya. Pengukuran dilakukan pada 14 dan 15 April 2018 dengan metode survei statik diferensial dengan desain pengukuran radial 8 baseline dengan Panjang baseline $10 \mathrm{KM}$, dan $15 \mathrm{KM}$ masing - masing berjumlah 4 baseline. Desain Pengukuran dapat dilihat pada Gambar 3. Pengukuran dilakukan selama satu jam dengan interval 5 detik dan sudut elevasi (mask angle) 15․ Titik ikat (base point) berada di BM ITS 01 di depan gedung Rektorat Institut Teknologi Sepuluh Nopember Surabaya.

\section{Peralatan}

- Perangkat Keras

a. Receiver GNSS hi Target V30

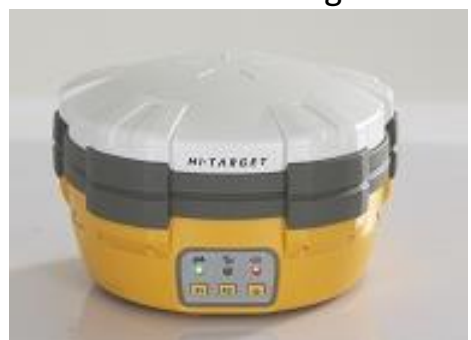

Gambar 2. Receiver GNSS Hi Target V30

- Perangkat Lunak

a. HGO ( Hi Target Geomatics Office ) Digunakan Untuk melakukan konversi data dari format .GNS menjadi Format Rinex.

b. Topcon Tools 8.2.3

Digunakan untuk pengolahan perhitungsn posisi

\section{Tahapan Penelitian}

Tahap dari penelitian ini dijelaskan pada uraian berikut:

a. Studi Literatur
Tahap studi literatur dilakukan dengan mencari referensi yang berkaitan dengan masalah yang diangkat dalam penelitian baik cetak berupa buku - buku referensi mengenai pengkururan GNSS maupun melalui website dan paper - paper yang tersedia secara online di internet.

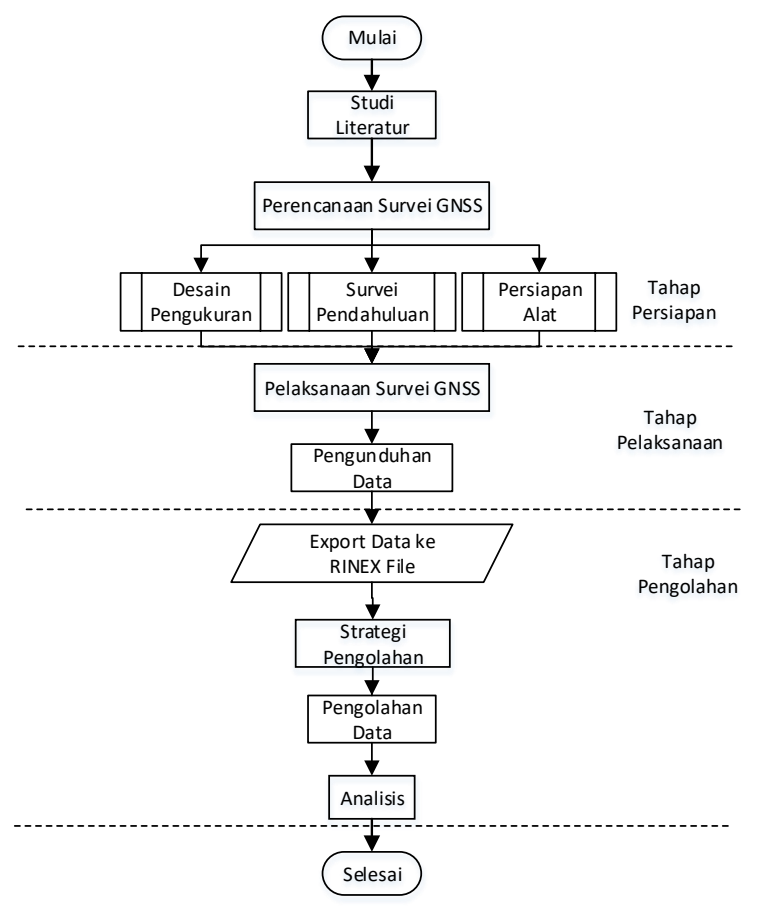

Gambar 3. Diagram Alir Penelitian

\section{b. Perencanaan Survei GNSS}

Pada tahap ini dilakuakan perencanaan sebelum melakukan survei,

- Pembuatan desain

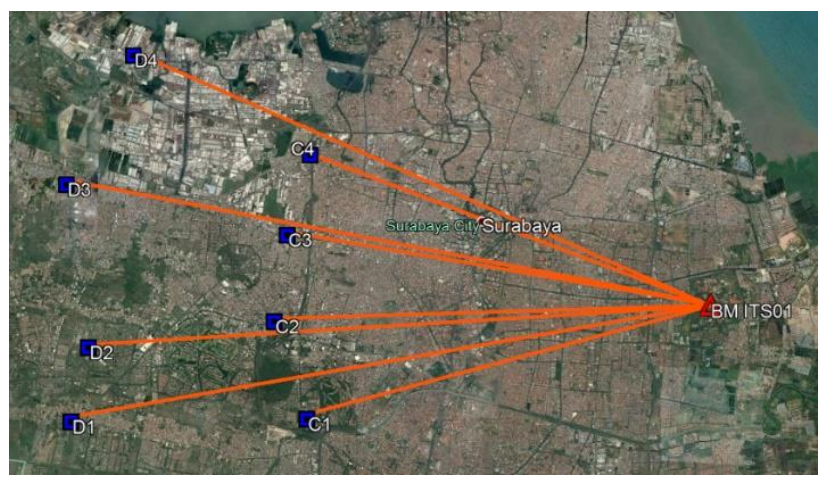

Gambar. 1 Desain Pengukuran penelitian

Titik pengukuran berada di area Kota Surabaya sejumlah total 8 baseline dengan Panjang baseline 10KM dengan kode titik $\mathrm{C}$, dan $15 \mathrm{KM}$ dengan 
kode titik $D$, masing - masing sebnayak 4 baseline dengan BM ITS 01 sebagai control point.

- Survei Pendahuluan

Dilakukan survei lokasi sesuai dengan desain yang telah dibuat, apakah lokasi memungkinkan untuk dilakukannya pengukuran atau harus ganti lokasi yang memungkinkan.

- Persiapan alat.

Mempersiapkan alat yang akan digunakan untuk pengukuran penelitian, mengecek kelengkapan receiver yang digunakan.

c. Pelaksanaan Survei GNSS

Pada tahap ini dilakukan pengukuran survei GNSS sesuai dengan desain yang sudah dibuat sebelumnya. Pengukuran dilakukan pada 14 dan 15 April 2018. perekaman data diambil dengan menggunakan receiver $\mathrm{Hi}$ Target V30 yang dapat menangkap sinyal GPS, GLONASS, dan BEIDOU.

d. Pengunduhan Data

Dilakuakan proses pengunduhan data hasil pengukuran.

e. Strategi Pengolahan dan Pengolahan Data Pada proses ini dilakukan pemilihan data GPS, GLONASS, dan BEIDOU yang kemudian dilakukan pengolahan dengan 6 strategi yang berbeda. Perbedaannya berada pada penggunaan kombinasi satelit yang berbeda - beda anatar strategi, yaitu :

1.Menggunakan data GPS + GLONASS + BEIDOU,

2. Menggunakan data GPS+ GLONASS,

3. Menggunakan data GPS + BEIDOU,

4. Menggunakan data GLONASS + BEIDOU,

5. Menggunakan data GPS, dan

6. Menggunakan GLONASS

Pengolahan dilakukan dengan menggunakan software komersil pengolah GNSS yaitu Topcon Tools 8.2.3.

f. Analisis

Setelah hasil selesai diolah, dilakukan analisis terhadap hasil ke enam strategi yang digunakan. Analisis meliputi perbandingan RMS error dan perbandingan nilai koordinat.

\section{HASIL DAN ANALISA}

\section{Hasil Pengolahan Posisi}

Hasil pengolahan menghasilkan nilai koordinat yang sudah ada pada sistem proyeksi UTM zona 49S, RMS E horizontal dan vertical setelah dilakukan proses post-processing. Pada pengolahan ini langsung dilakukan proses pada keseluruhan 8 baseline yang ada berdasarkan dengna kombinasi satelit yang digunakan.

\section{Analisis Perbedaan Koordinat Hasil Pengolahan Data}

- Analisis Hasil Koordinat Strategi 1 dan 2

Pada hasil yang didapatkan dari pengolahan dengan software Topcon Tools 8.2.3 strategi 1 dengan menggunakan satelit GPS + GLONASS + BeiDou terhadap strategi 2 yang menggunakan satelit GPS + GLONASS memiliki hasil yang sama. tidak terjadi perubahan pada nilai koordinat yang ada. Nilai Northing, Easting, dan Elevasi memiliki nilai yang sama.sehingga selisih dari koordinat dari strategi 1 dan strategi 2 adalah 0 untuk semua titik. Dari hasil ini dapat dikatakan bahwa dengan penambahan sinyal BeiDou tidak mempengaruhi proses pengolahan jika dikombinasikan dengan GPS+GLONASS.

\section{- Analisis Hasil Koordinat Strategi 1 dan 3} Perbedaaan hasil koordinat pada strategi 1 dan strategi 3 menggunakan kombinasi GPS + GLONASS + BeiDou terhadap GPS + BeiDou yang mana disini hasil dari GPS + GLONASS + BeiDou dijadikan sebagai acuan atau dianggap paling benar.

Tabel 1. Selisih Koordinat Strategi 1 dan Strategi 3

\begin{tabular}{cccc}
\hline TITIK & Northing $(\mathrm{m})$ & Easting $(\mathrm{m})$ & Elevation $(\mathrm{m})$ \\
\hline C1 & 0.017 & 0.019 & 0.001 \\
C2 & 0.001 & 0.007 & 0.022 \\
C3 & 0.002 & 0.005 & 0.016 \\
C4 & 0.003 & 0.017 & 0.013 \\
D1 & 0.029 & 0.034 & 0.059 \\
D2 & 0.002 & 0.001 & 0.029 \\
D3 & 0.003 & 0.007 & 0.004 \\
D4 & 0.005 & 0.026 & 0.031 \\
\hline
\end{tabular}




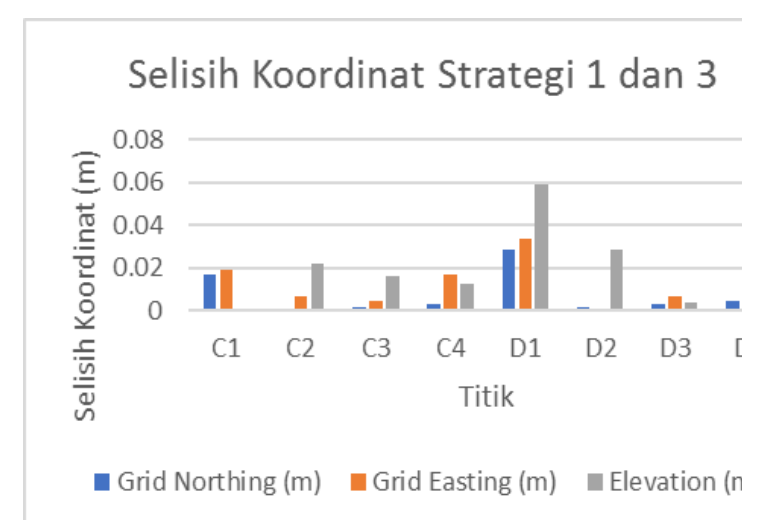

Gambar 5. Perbedaan Koordinat Strategi 1 dan 3

Setelah dilakukan pengurangan dari hasil koordinat strategi 3 terhadap strategi 1, selisih perbedaan koordinat dirubah menjadi nilai absolut. Hal ini dilakukan untuk menghindari terdapatnya selisih koordinat yang bernilai negatif Perbedaan selisih koordinat ini dapat dilihat pada Tabel 1. dan Gambar 5.

Berdasarkan pada Tabel 1 dan Gambar 5 menunjukkan bahwa dengan digunakan atau tidak satelit GLONASS memberikan pengaruh pada hasil koordinat yang didapatkan. Hasil koordinat mengalami perubahan disemua aspek, baik itu N, E, dan Z. selisih terbesar terdapat pada titik D1 dimana terjadi perubahan paling besar yaitu dengan nilai $0.029 \mathrm{~m}$ untuk northing, $0.034 \mathrm{~m}$ untuk easting dan $0.059 \mathrm{~m}$ untuk elevasi.

\section{- Analisis Hasil Koordinat Strategi 1 dan 4}

Perbedaan koordinat ini yang digunakan adalah hasil kombiasi dari penggunaan satelit GLONASS + BeiDou yang dikurangi terhadap hasil koordinat penggunaan satelit GPS + GLONASS + BeiDou yang yang sebelumnya dianggap benar. Sama seperti analisis strategi 1 dan 3 sebelumnya, yang mana hasil selisih dibuat kenilai absolut untuk menghindari nilai negatif. Hasil perbedaan koordinat dapat dilihat pada Tabel 2 dan Gambar 6 berikut.
Tabel 2. Perbedaan Koordinat Strategi 1 dan 4

\begin{tabular}{cccc}
\hline TITIK & Northing $(\mathrm{m})$ & Easting $(\mathrm{m})$ & Elevation $(\mathrm{m})$ \\
\hline C1 & 0.174 & 1.068 & 1.399 \\
C2 & 0.063 & 0.034 & 0.075 \\
C3 & 0 & 0.001 & 0.002 \\
C4 & 0.054 & 0.009 & 0.18 \\
D1 & 0.036 & 0.04 & 0.075 \\
D2 & 0.004 & 0.019 & 0.006 \\
D3 & 0.001 & 0.002 & 0.047 \\
D4 & 0.414 & 0.355 & 0.386 \\
\hline
\end{tabular}

Selisih Koordinat Strategi 1 dan 4

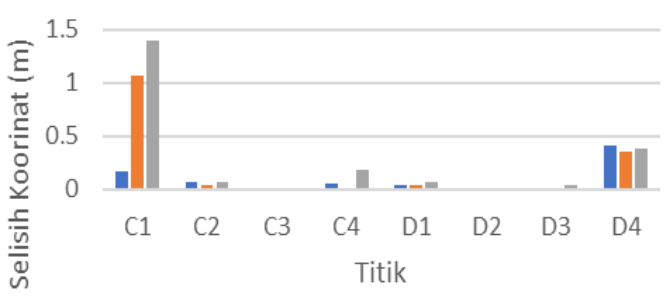

- Grid Northing (m) a Grid Easting (m) Elevation (m)

Gambar 6. Perbedaan Koordinat Strategi 1 dan 4

Berdasarkan pada Tabel 2 dan Gambar 6 didapatkan hasil yang tidak bagus pada salah satu titik, yaitu pada titik C1, selisih koordinat mencapai lebih dari $1 \mathrm{~m}$ untuk nilai nilai $E$ dan $Z$. selisih yang cukup besar juga terdapat pada titk D4 yaitu diatas $0.3 \mathrm{~m}$ di semua koordinatnya. Sedangkan untuk titik yang lainnya berada dibawah $0.08 \mathrm{~m}$. akan tetapi disini terdapat 1 titik yang tidak mengalami perubahan pada salah koordinat northing yaitu pada titik C3 selisih nilai $\mathrm{N}$ adalah $0 \mathrm{~m}$. hal ini menunjukkan bahwa tidak digunakannya satelit GPS memberi pengaruh yang cukup besar.

\section{- Analisa Hasil Koordinat Strategi 1 dan 5}

Perbedaaan hasil koordinat pada strategi 1 dan strategi 5 menggunakan kombinasi GPS + GLONASS + BeiDou terhadap GPS saja, yang mana disini sama sepertinya analisis sebelumnya, hasil dari GPS + GLONASS + BeiDou dijadikan sebagai acuan atau dianggap paling benar. Hasil perbedaan 
koordinat dapat dilihat pada Tabel 3 dan Gambar 6 berikut.

Tabel 3. Perbedaan Koordinat Strategi 1 dan 5

\begin{tabular}{cccc}
\hline TITIK & Northing $(\mathrm{m})$ & Easting $(\mathrm{m})$ & Elevation $(\mathrm{m})$ \\
\hline C1 & 0.017 & 0.019 & 0.001 \\
C2 & 0.001 & 0.007 & 0.022 \\
C3 & 0.002 & 0.005 & 0.016 \\
C4 & 0.003 & 0.017 & 0.013 \\
D1 & 0.029 & 0.034 & 0.059 \\
D2 & 0.002 & 0.001 & 0.029 \\
D3 & 0.003 & 0.007 & 0.004 \\
D4 & 0.005 & 0.026 & 0.031 \\
\hline
\end{tabular}

\section{Selisih Koordinat Strategi 1 dan 5}

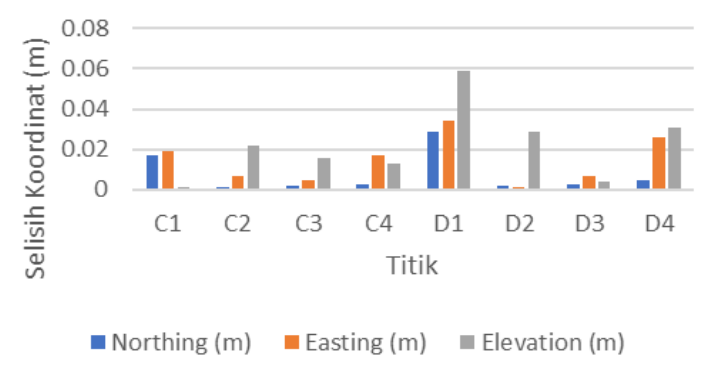

Gambar 7. Selisih Koordinat Strategi 1 dan 5

Berdasarkan pada Tabel 3 dan Gambar 7 menunjukkan bahwa dengan menggunakan satelit GPS mendapatkan hasil yang sama sperti penggunaan satelit GPS + BeiDou. Hal ini isa dikatakan bahwa sinyal BeiDou tidak mempengaruhi sinyal GPS. Sedangkan untuk hasil koordinat mengalami perubahan disemua aspek, baik itu N, E, dan Z. selisih terbesar terdapat pada titik D1 dimana terjadi perubahan paling besar yaitu dengan nilai $0.029 \mathrm{~m}$ untuk northing, $0.034 \mathrm{~m}$ untuk easting dan $0.059 \mathrm{~m}$ untuk elevasi jika dibandingkan dengan hasil koordinat satelit GPS + GLONASS + BeiDou

\section{- Analisa Hasil Koordinat Strategi 1 dan 6}

Perbedaan koordinat yang terakhir yaitu pada hasil kombiasi dari penggunaan satelit GLONASS yang dikurangi terhadap hasil koordinat penggunaan satelit GPS + GLONASS + BeiDou. Hasil perbedaan koordinat dapat dilihat pada Tabel 4 dan Gambar 8 berikut.

Tabel 4. Perbedaan Koordinat Strategi 1 dan 6

\begin{tabular}{cccc}
\hline TITIK & Northing $(\mathrm{m})$ & Easting $(\mathrm{m})$ & Elevation $(\mathrm{m})$ \\
\hline C1 & 0.296 & 0.371 & 0.598 \\
C2 & 0.705 & 0.091 & 0.429 \\
C3 & 0 & 0.001 & 0.002 \\
C4 & 0.057 & 0.009 & 0.186 \\
D1 & 0.036 & 0.04 & 0.075 \\
D2 & 0.004 & 0.019 & 0.006 \\
D3 & 0 & 0.003 & 0.044 \\
D4 & 0.414 & 0.359 & 0.387 \\
\hline
\end{tabular}

\section{Selisish Koordinat Strategi 1 dan 6}

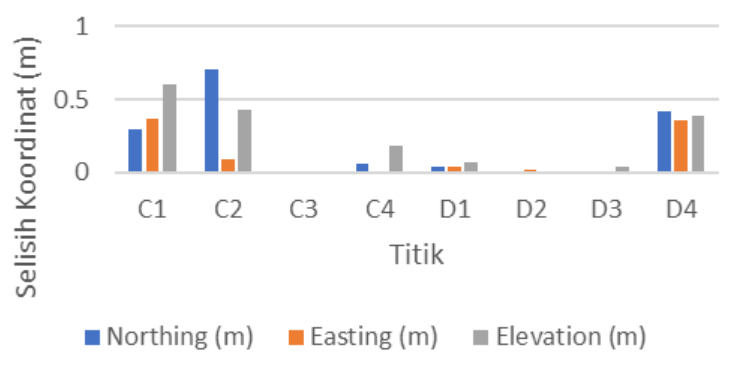

Gambar 8. Perbedaan Koordinat Strategi 1 dan 6

Berbeda dengan penggunaan satelit GPS saja, berdasarkan pada Tabel 4 dan Gambar 8 menunjukkan bahwa dengan menambahkan penggunaan satelit BeiDou mempengaruhi hasil satelit GLONASS. Hal ini dapat dilihat dari nilai selisish yang berbeda dengan strategi 4 . Pada strategi 4 yang terdapat nilai diatas $1 \mathrm{~m}$ pada titik $\mathrm{C} 1$ berkurang menjadi $0.371 \mathrm{~m}$ untuk nilai $\mathrm{E}$. dan disini terdapat 2 nilai koordinat yang tidak mengalami perubahan, yaitu pada northing titik C3 dan D3. Sehingga dapat dikatakan bahwa penggunaan satelit BeiDou memperbaiki ketelitian posisi satelit GLONASS. 


\section{Analisa RMS Error}

- RMS Error Baseline $10 \mathrm{KM}$

Tabel 5. RMS Error Horizontal Baseline $10 \mathrm{KM}$

\begin{tabular}{ccccccc}
\hline & \multicolumn{6}{c}{ Strategi } \\
\cline { 2 - 7 } Titik & 1 & 2 & 3 & 4 & 5 & 6 \\
\hline C4 & 0.007 & 0.007 & 0.006 & 0.018 & 0.006 & 0.018 \\
C3 & 0.019 & 0.019 & 0.033 & 0.016 & 0.033 & 0.016 \\
C2 & 0.014 & 0.014 & 0.015 & 0.088 & 0.015 & 0.585 \\
C1 & 0.011 & 0.011 & 0.01 & 0.445 & 0.01 & 0.363 \\
\hline
\end{tabular}

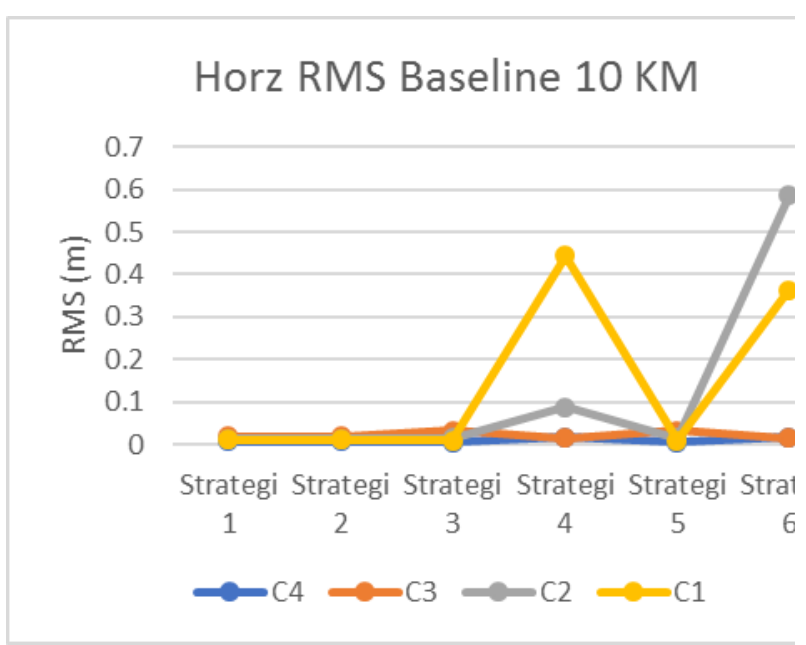

Gambar 9. RMS Error Horizontal Baseline $10 \mathrm{KM}$

Hasil dari pengolahan memiliki nilai RMS error horizontal dan vertikal. Nilai RMS error ini menunjukkan akurasi dari penggukuran yang dilakukan semakin kecil atau mendekati nol nilai yang didapatkan, maka semain bagus pula akurasi yang didapatkan. Hasil RMS error dapat dilihat pada Tabel 5 dan Gambr 9 untuk RMS error horizontal, dan Tabel 6 dan Gambar 10 untuk RMS error vertikal.

Tabel 6. RMS Error Vertikal Baseline $10 \mathrm{KM}$

\begin{tabular}{ccccccc}
\hline & \multicolumn{6}{c}{ Strategi } \\
\cline { 2 - 7 } Titik & 1 & 2 & 3 & 4 & 5 & 6 \\
\hline C4 & 0.012 & 0.012 & 0.011 & 0.046 & 0.011 & 0.045 \\
C3 & 0.014 & 0.014 & 0.053 & 0.011 & 0.053 & 0.011 \\
C2 & 0.023 & 0.023 & 0.023 & 0.178 & 0.023 & 0.359 \\
C1 & 0.02 & 0.02 & 0.024 & 0.38 & 0.024 & 0.624 \\
\hline
\end{tabular}

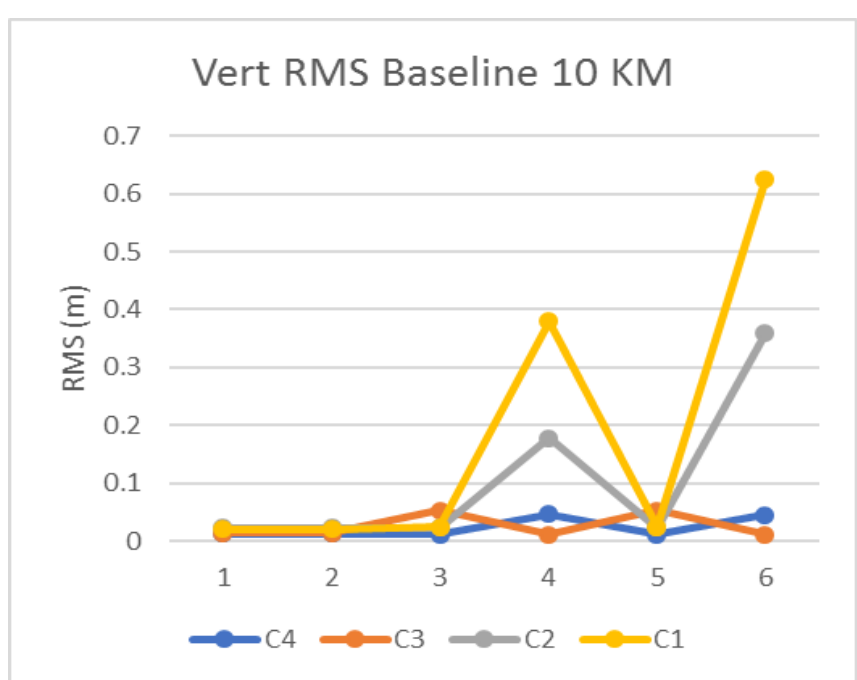

Gambar 10. RMS Error Vertikal Baseline 10 KM

Dari Gambar 9 dan Gambar 10 menunjukkan bahwa nilai RMS error mengalami perubahan yang cukup besar pada strategi 4 dan strategi 6. Pada RMS error horizontal strategi 4 dengan penambahan satelit BeiDou menghasilkan nilai yang lebih kecil jika dibandingkan dengan strategi 6 .

\section{- RMS Error Baseline 15 KM}

Hasil RMS error dapat dilihat pada Tabel 7 dan Gambar 11 untuk RMS error horizontal, dan Tabel 8 dan Gambar 12 untuk RMS error vertikal.

Tabel 7. RMS Error Horizontal Baseline 15 KM

\begin{tabular}{ccccccc}
\hline \multirow{7}{*}{ Titik } & \multicolumn{7}{c}{ Strategi } \\
\cline { 2 - 7 } & 1 & 2 & 3 & 4 & 5 & 6 \\
\hline D4 & 0.008 & 0.008 & 0.009 & 0.051 & 0.009 & 0.056 \\
D3 & 0.008 & 0.008 & 0.009 & 0.013 & 0.009 & 0.013 \\
D2 & 0.007 & 0.007 & 0.008 & 0.017 & 0.008 & 0.018 \\
D1 & 0.008 & 0.008 & 0.008 & 0.013 & 0.008 & 0.013 \\
\hline
\end{tabular}




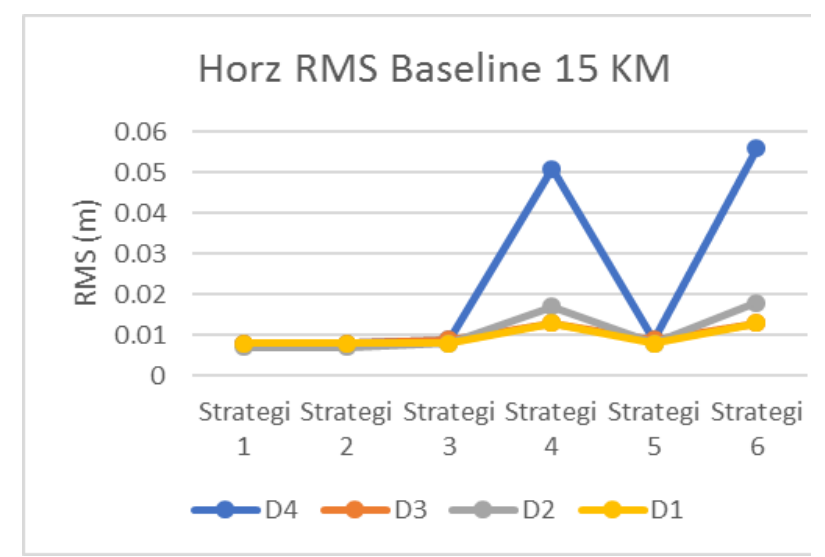

Gambar 11. RMS Error Horizontal Baseline 15 KM

Tabel 8. RMS Error Vertikal Baseline 15 KM

\begin{tabular}{ccccccc}
\hline \multirow{2}{*}{ Titik } & \multicolumn{7}{c}{ Strategi } \\
\cline { 2 - 7 } & 1 & 2 & 3 & 4 & 5 & 6 \\
\hline D4 & 0.013 & 0.013 & 0.019 & 0.064 & 0.019 & 0.068 \\
D3 & 0.013 & 0.013 & 0.013 & 0.021 & 0.013 & 0.021 \\
D2 & 0.012 & 0.012 & 0.016 & 0.019 & 0.016 & 0.019 \\
D1 & 0.011 & 0.011 & 0.012 & 0.018 & 0.012 & 0.018 \\
\hline
\end{tabular}

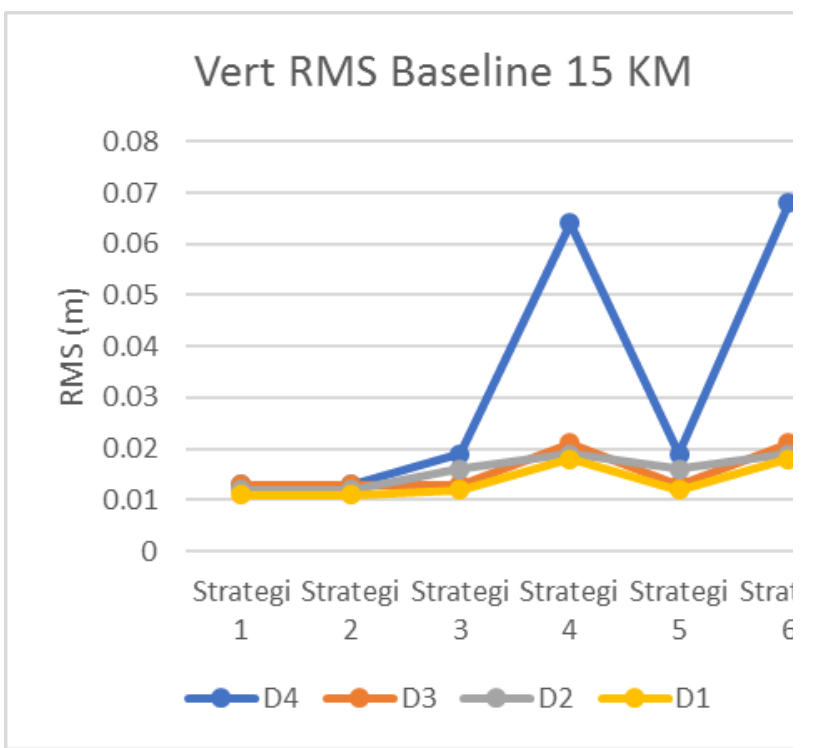

Gambar 12. RMS Error Vertikal Baseline 15 KM

Hasil dari RMS error baseline $15 \mathrm{KM}$ menunjukkan kecenderungan yang sama seperti pada baseline $10 \mathrm{KM}$, dimana nilai RMS terbesar terjadi pada pengolahan dengan menggunakan strategi 4 dan strategi 6.

\section{KESIMPULAN}

Penggunaan kombinasi satelit yang berbeda pada saat pengolahan data GNSS mempengaruhi nilai dari ketelitian yang didapatkan. Hasil yang berbeda didapatkan berdasarkan dengan strategi pengolahan yang digunakan.

Pengolahan dengan menggunakan strategi 1 dan strategi 2 menghasilkan nilai yang sama baik dilihat dari selisih koordinat ataupun nilai RMS error yang ada. Nilai yang dihasilkan dengan menggunakan strategi pengolahan 1 dan strategi pengolahan 2 mendapatkan hasil yang paling bagus dari ke 6 strategi yang digunakan. Hal ini dilihat dari rata - rata nilai RMS error pada strategi pengolahan 1 dan 2 memiliki nilai terkecil jika dibandingkan dengan strategi yang lainnya. Sedangkan hasil yang kurang baik didapatkan dengan menggunakan strategi pengolahan 4 dan 6 . Hal ini ditunjukan dengan selisih koordinat dan nilai RMS error yang dihasilkan dari kedua strategi tersebut memiliki nilai yang paling besar.

Penggunaan satelit BeiDou tidak terlalu memberi pengaruh terhadap satelit GPS, akan tetapi penggunaan satelit BeiDou menambah ketelitian dari satelit GLONASS. Hal ini ditunjukkan dengan adanya pengurangan nilai pada selisih koordinat dan RMS error yang dihasilkan.

\section{UCAPAN TERIMA KASIH}

Penulis W.R.. mengucapkan terima kasih kepada mahasiswa Teknik Geomatika angkatan 2014 Institut Teknologi Sepuluh Nopember Surabaya atas dukungan dan batuan dalam pengambilan data pengukuran GNSS.

\section{DAFTAR PUSTAKA}

Lechner, W. \& Baumann, S., Global Navigation Satellite systems. (2000).

Bakara, J,. Perkembangan Sistem Satelit Navigasi Global dan Aplikasinya.( 2011)

NovAtel Inc,. An Itroduction to GNSS .( 2015).)

Abidin, H. Z.,. Penentuan Posisi dengan GPS dan Aplikasinya. (2007

Rahmad, A.A., Comparative Analysis on Data Processing of Mount Merapi Gps Cors Station By Using Scientific and Commercial Software. (2016).

El-Rabbany, Introduction to GPS The Global 
Positioning System.(2002)

Izman , Y. \& Rudianto, B.,. Analisis Komperatif Ketelitian Posisi Titik Hasil Pengukuran dari Satelit Gps dan Satelit Glonass. (2011)

Gumilar, I. Pamungkas, A. Abidin H. Z. Bramanto, B. \& Adi, F. S. The Contribution of BeiDou Positioning System for Accuracy Improvement : A Perspective from Bandung, Indonesia. ResearchGate (2016).

Hi Target. Hi Target Products V30 GNSS RTK System , 2015. [Online]. available : http://en.hitarget.com.cn/product/detail.aspx? node $=1$ $01005001 \&$ pid $=108 \&$ catid $=3$. [accessed 30 $12018]$.

GLONASS. GLONASS HISTORY, 2018. [Online]. available : https://www.glonassiac.ru/en/guide/index.php [accessed 131 2018].

IAC. Information and Anaysis center for Positioning, Naviagtion and Timing. Beidou Navigation Satelite System. 2017. [Online]. available : https://www.glonass-

iac.ru/en/guide/beidou.php. [accessed 30 12 2017] 